\title{
Use of Foreign Workers in the Mining Sector
}

\author{
Adnan Hamid \\ Lecturer of Law Studies S1 Program \\ University of Pancasila \\ Jakarta, Indonesia \\ adnan_hamid@univpancasila.ac.id
}

\begin{abstract}
Article 27 paragraph (2) of the 1945 Constitution, states that "every citizen has the right to work and livelihood that is suitable for humanity". This artide means that the $\mathrm{S}$ tate is obliged to provide employment for its citizens by giving the widest possible opportunity to its citizens to obtain employment. Meanwhile Article $28 \mathrm{D}$ paragraph (2) of the 1945 Constitution states that "every person has the right to work and receive fair and decent remuneration and treatment in an employment relationship". This provision brings the consequence of a person's basic right to get a job wherever he is. The current era of globalization has an impact on the entry of foreign workers (TKA) in filling in existing jobs. Law No. 13 of 2003 concerning Manpower has limitedly regulated the use of foreign workers who will work in Indonesia. Furthermore, in order to attract foreign investors to invest their capital in Indonesia, the Government has revoked the Presidential Regulation (Perpres) Number 72 of 2014 by imposing Presidential Regulation Number 20 of 2018 on the Use of Foreign Workers. Specifically for the use of foreign workers in the mining sector further regulated in the Minister of Energy and Mineral Resources Regulation No. 25 of 2018 concerning the Exploitation of Mineral and Coal Mining (Permen ESDM 25/2018) as well as in the Minister of Manpower Regulation number 35 of 2015.
\end{abstract}

Keywords - manpower, foreign workers, legislations, employment.

\section{INTRODUCTION}

The era of globalization led to the emergence of labor market liberalization which was marked by the movement of labor and the entry of foreign workers (TKA) in filling in existing jobs. Foreign workers who come and fill jobs in other countries, including in the sense of being migrant workers. In the international context, the notion of migrant workers itself is contained in the International Convention of 1990 , which is defined as someone who will, in the middle, have done paid work in a country, where he is not a citizen ". According to Marsha Chien, the United Nations defines a "migrant worker" as "a person who is to be engaged, is engaged or has been engaged in a remunerated activity in the State which he or she is not national." [1] Meanwhile the International Labor Organization (ILO) defines migrant workers as migrants, or has migrated from one country to another, with a description that the person will be employed by someone who is not himself, including anyone who is usually recognized as a migrant for work. The freedom to choose a job for everyone to work wherever is found is in Article 23 of the Universal Declaration of Human Rights which states that: Every person has the right to get a job, free to choose a job, fair and pleasant conditions of a work environment and get protection from unemployment[2].
Meanwhile Law No. 13 of 2003 concerning Manpower has regulated such that foreign workers who will work in Indonesia do not close the opportunity for workers from Indonesia (local labor) to obtain employment. The arrangement aims to provide protection by giving local workers a chance to obtain employment. In its development, the Government wants an acceleration in economic growth by opening up the widest entry of foreign investment. One of the efforts made by the Government by applying Presidential Regulation Number 20 of 2018 concerning the Use of Foreign Workers. The existence of the Perpres is expected to encourage foreign investment to invest in Indonesia because the previous Presidential Regulation is considered not conducive. The enactment of Presidential Decree Nu mber 20 of 2018 itself, caused a polemic because it was considered "inappropriate" and even "contradicted" with the Manpower Act. The Perpres should maintain employ ment opportunities for local workers and not vice versa to make special rules that provide allowances for foreign workers [3]. BPS noted that the number of foreign workers working in Indonesia continued to increase, even BPS said there was a correlation between the number of foreign workers who entered Indonesia with an increase in unemployment. For example, in 2016 the unemployment rate was $7.03 \%$, while in 2017 it was $7.04 \%$, or in other words that the unemployment rate rose by $0.14 \%$ [4]. The results of a 1991 study of Lakonde \& Topel and Altonji \& Card, which used the results of population census data in the US, found that the influence of foreign workers on employment opportunities for local workers was negative, meaning reduced employment opportunities for local workers in the country [4]. However, if the number of foreign workers in Indonesia, compared to the number of Indonesian workers who work as migrant workers abroad, the number reaches 9 million people, is very small[4]. Meanwhile Cabinet Secretary Pramono Anung stressed that the Perpres actually only facilitates the administration of the use of foreign workers, especially for middle to upper class workers, who have been complicated and have long been involved.[5]. One sector that foreign investors are interested in investing in Indonesia is the mining sector. In particular the mechanism for the use of foreign workers in the mining sector is regulated through the Regulation of the Minister of Energy and Mineral Resources No. 25 of 2018 concerning the Exploitation of Mineral and Coal Mining (Permen ESDM 25/2018) and Minister of Manpower (Permanaker) Regulation number 35 of 2015. In addition, it must still be guided by the Manpower Act. The main problem in this writing is how is the legal policy in using foreign workers in the mining sector? 


\section{DISCUSSION}

Along with the increase in foreign investment in the mining sector and the increase in the number of foreign workers working in Indonesia, of course, it must be followed by regulations that can provide a conducive work climate. This conducive work climate is not only for the benefit of the company, but also for the benefit of all workers including the TKA. Data from the Ministry of Manpower and Transmigration, noted that throughout 2017 there were 85,947 foreign workers working in Indonesia[3]. When viewed from the orig in of the region, the majority of foreign workers are on the island of Java (83\%) and cover the areas of DKI Jakarta (48\%), West Java (22\%), Banten $(9 \%)$ and East Java (3\%). The rest came from outside Java (17\%) covering several provinces in Riau Islands (11\%), East Kalimantan (4\%) and Bali (3\%)[6]. The use of foreign workers themselves cannot be avoided as a consequence of the entry of foreign investment and the need for global competition, which requires skilled and skilled foreign workers. Global competition in the business world, especially for companies that have international networks, requires a skilled workforce and has certain competencies. It is expected that by recruiting foreign workers with certain skills and competencies, it will provide benefits for the company in facing global competition. Greenwood and Mc Dowel argued that the entry of foreign workers could encourage economic growth through increasing public demand for goods and services produced and capital formation in the country concerned. Meanwhile according to Jodge and Mancurz argued otherwise, that the entry of foreign workers brought unfavorable influence on economic growth, employ ment opportunities and wage rates for local workers. On the other hand, Orman and Meicle, believe that the form of complementary relations between foreign workers and local workers has provided considerable benefits in encouraging an increase in the rate of economic growth such as, among others, the obligation to transfer of knowledge[4]. Article 1 paragraph 13 of Law Number 13 of 2003 concerning Manpower, provides the definition of foreign workers (TKA): foreign nationals hold ing vis as with the intention of working in the territory of Indonesia. The Manpower Act provides arrangements and restrictions for foreign workers themselves, both for the type of work and for the period of time in the work. Strictly speaking, this Law requires planning for the use of foreign workers by making a Plan for the Use of Fo reign Workers (RPTKA). So the existence of RPTKA is mandatory or mandatory in applying for permission to use foreign workers in one company. In addition there are other obligations where companies using TKA must appoint counterparts who come from local workers. This is because the use of foreign workers is limited by the length of time working in Indonesia. TKA in the end must provide opportunities for local workers to be able to replace it through the transfer of knowledge. The skill transfer process is carried out through a mentoring process as long as the TKA works. In connection with the limitation of the period of time in carrying out a work relationship, the legal relationship that occurs between the employer and the TKA as the recipient of the work is by making a work agreement for a certain time (PKWT) or also known as a work contract. This is in line with Article 42 paragraph (4) which states that "foreign workers can be employed in Indonesia only in employment relationships for certain positions and at certain times". This means that the use of foreign workers in Indonesia must be limited even to certain positions where it should be able to be filled with local workers. Therefore foreign workers can only fill positions that cannot be filled by local workers or because there are still few local workers who have certain skills.

Regarding the use of foreign workers in the mining sector, it remains to be guided by this Manpower Act, although it is technically regulated further in the Regulation of the Minister of Energy and Mineral Resources Number 25 of 2018 concerning the Exploitation of Mineral and Coal Mining. In general the use of foreign workers, as regulated in the Manpower Act which includes:

1. Licensing, that is, the Company as an employer who will employ foreign workers must have written permission from the Minister or the official appointed for that. Written permission by the Minister or the appointed official is a permit to use TKA or commonly abbreviated as IMTA. The reason for the need for a permit is that the use of the TKA is carried out selectively in order to optimally utilize the local workforce.

2. A certain period of time, that is, each foreign worker can only be employed in Indonesia in a working relationship for a certain time. Foreign workers whose working period is expired and cannot be extended for their employment can be replaced by other foreign workers.

3. The existence of RPTKA, which is where the employer who will use TKA must first have the RPTKA that has been approved by the Minister or the official appointed for it. In the RPTKA, at least contains the following information:

a. Reasons for using foreign workers;

b. Position and / or position of TKA in the company's organizational structure;

c. The period of use of foreign workers; and

d. Appointment of local workforce as assistants for foreign workers.

4. The existence of competency standards, namely the existence of a standard of competence that must be possessed by foreign workers who will work in Indonesia, including the existence of knowledge, expertise, skills in certain fields and understanding of Indonesian culture.

5. Obligation to appoint accompanying workforce for foreign workers, namely employers who are obliged to:

a. Appoint local workers as assistants for foreign workers to transfer technology and transfer skills from foreign workers;

b. Carrying out education and job training for local workers as assistants of foreign workers in accordance with the qualifications of positions occupied by foreign workers; (This provision does not apply to foreign workers who occupy positions of directors and / or commissioners).

6. Prohibition of occupying certain positions, namely where foreign workers are prohibited from occupying positions in charge of personnel and / or certain positions. 
7. Obligation of compensation, that is, the employer is obliged to pay compensation for each foreign worker employed.

8. Making a Report, that is, the employer is obliged to report the use of foreign workers and their companions periodically every 6 months

9. The obligation to repatriate foreign workers, namely employers who employ foreign workers must repatriate to their home country after the employment relationship ends.

However, in Article 10 paragraph 1 of Presidential Regulation number 20 of 2018, it is stated that the use of foreign workers does not require the existence of RPTKA for certain jobs determined by the Government. This is certainly contrary to Article 43 paragraph (1) of the Manpower Act which states that the use of foreign workers is based on the existence of RPTKA. Furthermore, in Article 13 of the Presidential Regulation, it gives an exception that in an emergency, it can use foreign workers without RPTKA first. This creates a gap for employers to avoid the obligation to make RPTKA. Furthermore, in Article 17 of this Regulation, there are rules which state the provisions regarding limited stay visas (VITAS) that can be taken care of in the representative of the Republic of Indonesia abroad, thus giving space for foreign workers to be able to work first and then take care of work permits. Not to mention that in the Perpres there is no explicit regulation on the obligation to appoint local workers as companions of TKA in transferring knowledge or transfer of expertise. The latest developments in the use of foreign workers in the mining sector, have also revoked the regulations contained in Ministerial Regulation No. 31 of 2013 concerning the provisions on the procedures for the use of foreign workers and the development of Indonesian workers in oil and gas business activities. The purpose of the revocation is simply to simplify the licensing procedure for foreign workers, so that it is faster and can increase investment interest[7]. Therefore, the current permit to use foreign workers in the oil and gas sector is guided by the Minister of Manpower regulation. So mining service companies that will use TKA, must prepare:

1. Whereas a mining service company where a foreign worker will work, has a Mining Business License (IUP) which is the initial requirement for mining service companies to operate in Indonesia.

2. That mining service companies that will employ foreign workers are obliged to have permits from the Ministry of Manpower or related institutions. Previously, the company must first get approval from the Ministry of Energy and Mineral Resources, the Governor, or the Mayor / Regent according to their authority.

3. That foreign workers who will work, must obtain a letter of recommendation for permission to use foreign workers (IMTA) from the Directorate General of Oil and Gas.

4. That mining service companies are obliged to submit RPTKA applications that must be approved by the Ministry of Manpower.

5. Whereas a mining service company must submit an application to the Director General of Manpower Placement Guidance and Expansion of Employment
Opportunities through the Director of Control of Foreign Workers Use. The application process can be done online by attaching the following documents:

a. Application form

b. Reasons for using Foreign Workers;

c. Business permit;

d. Company Articles of Association and its amendments (if any);

e. Organizational structure of the company;

f. Company domicile certificate;

g. Letter of recommendation from the institution regarding the position to be occupied by foreign workers;

h. Corporate Taxpayer Identification Number (NPWP);

i. Letter of appointment of Indonesian Workers as a companion for foreign workers;

j. Mentoring program reports that are in accordance with the expertise of foreign workers;

k. Mandatory Report on Labor in accordance with Law Number 7 of 1981.

6. That a mining service company must submit an application online to the Director of Control of the Use of Foreign Workers. Some documents that must be prepared are as follows:

1. RPTKA that has been ratified

2. TKA passport;

3. Post photo TKA;

4. Letter of appointment of companion TKI

5. Educational certificate that matches the position requirements that will be occupied by foreign workers;

6. Competency certificate or having 5 (five) years of work experience in accordance with the position of TKA;

7. Draft work agreement or agreement to do work;

8. Proof of insurance policy in an Indonesian legal insurance company; and

9. Recommendations from authorized agencies.

\section{CONCLUSION}

In closing in this paper, the authors conclude that the legal policy stipulated in the use of foreign workers in the mining sector must still refer to Law Number 13 of 2003 concerning Manpower, Perpres number 20 of 2018, Decree of the Minister of Manpower and Transmigration number 12 Year 2018 and Regulation of the Minister of Energy and Mineral Resources No. 25 of 2018 which essentially allows the use of foreign workers in a selective and limited manner within the framework of 'transfer of knowledge' to local workers.

\section{REFERENCES}

[1] M. Chien, "When Two Laws are Better than One: Protecting the Rights of Migrant Workers," Berkeley J. Int. Law, vol. 28, no. 1, p. 17,2010 .

[2] Suratman, Hukum Ketenagakerjaan Indonesia. Jakarta: Indeks, 2010.

[3] "Perpres Penggunaan TKA Mesti Diatur Rinci dalam Permenaker." [Online]. Available: http://www.hukumonline.com/berita/baca/lt5ae3197ea7d0b/perprespenggunaan-tka-mesti-diat ur-rinci-dalam-permenaker. [Accessed: 27-Apr-2018]. 
[4] "Tenaga Kerja Asing dan Pertumbuhan Ekonomi Nasional." [Online]. Available: https://news.detik.com/kolom/4010317/tenagakerja-asing-dan-pert umbuhan-ekonomi-nasional. [Accessed: 08May-2018].

[5] "Cabinet Secretary Pramono Agung." [Online]. Available: http://set kab.go.id/bukan-unt uk-non-skill-seskab-perpres-tenagakerja-asing-untuk-level-manajer-ke-atas/. [Accessed: 18-Apr-2018].

[6] V. N. S. Lestari, D. Cahyono, and M. B. N. Wajdi, "Sistem
Pengupahan Di Indonesia," Econ. Econ. Islam. Law J., vol. 8, no. 2, p. 151, 2017.

[7] "Alasan Pemerintah Permudah Izin Tenaga Kerja Asing di Sektor Migas." [Online]. Available: https://www.liput an6.com/bisnis/read/3376894/alasan-pemerint ahpermudah-izin-tenaga-kerja-asing-di-sekt or-migas. [Accessed: 23Jul-2018]. 